\title{
Protection against Dental Carries by Passive Immunization with Hen Egg Yolk Antibody Using Cell Associated Glucosyltransferase of Streptococcus
} mutans

\author{
Sentila R ${ }^{1}$, Karthika S ${ }^{1}$, Michael A $^{2}$ and Gandhimathi $\mathbf{A}^{3}$ \\ ${ }^{1}$ Department of Microbiology, PSG College of Arts and Science, Coimbatore, India \\ ${ }^{2}$ Associate Professor and Head, Dept of Microbiology, PSG College of Arts and Science, Coimbatore, India \\ ${ }^{3} \mathrm{PhD}$ Scholar, Department of Microbiology, Karpagam University, Coimbatore, India
}

\begin{abstract}
Background: Dental caries is one of the most frequently encountered diseases. Of the oral bacteria, Streptococcus mutans is considered to be causative agent of dental caries in humans.

Aim: This study aims at formulating a dental composition using Chicken Egg yolk Antibodies (IgY).

Methodology: IgY was raised in 22 weeks old white leghorn chicken against CA-GTF antigen of Streptococcus mutans. The level of the antibody in serum was monitored and booster doses were given whenever necessary. The antibodies were purified from the egg yolk using PEG and Ammonium sulphate precipitation and DEAE cellulose ion exchange column chromatography.

Results and discussion: High titre of more than 1:10000 antibodies were detected by Indirect ELISA at $150^{\text {th }}$ day of observation. The IgY concentration in egg yolk was increased during the immunization period and reached maximum of $3.9 \mathrm{mg} / \mathrm{ml}$. The minimum agglutination concentration of $\mathrm{lg} Y$ against whole cell antigen of $S$. mutans was found to be 1:625. Similarly, when pre-immune lgY (control) were used no agglutination were observed. There was a decrease in Streptococcus mutans growth with increasing concentration of antibodies (IgY). The growth was not distinct when $25 \mu \mathrm{g} / \mathrm{ml}$ of IgY was added to the culture. Similarly, GTF activity was quantified by phenol-sulfuric acid method.

Conclusion: Total glucan synthesis by cell-associated GTF preparation from Streptococcus mutans was significantly inhibited by the addition of antibodies to CA-GTF. This raises the possibility of conferring passive protection against Streptococcus mutans-induced dental caries by using IgY from the eggs of the hens hyperimmune to Streptococcus mutans CA-GTF antigen. IgY specific to Streptococcus mutans can prevent the tooth decay by immobilizing bacteria and disabling bacteria's ability to convert sugar into acid, thereby preventing dental caries.
\end{abstract}

Keywords: Dental caries; Glucosyl transferase; Streptococcus mutans; IgY; Prevention

\section{Introduction}

The term caries means decay of tissue. It has affected the teeth of all nations irrespective of geographic and cultural differences. The incidence of caries increased as civilization advanced, mainly because of dietary habits. In India the incidence has gone up from 40 to around 80 percent during the past four decades. Presumably rising standards of living have led to increasing sugar intake. According to the survey made by the WHO, Dental caries has been increasing both in prevalence and severity for the last five decades [1].

Dental caries is caused predominantly due to the common oral bacterium, Streptococcus mutans (S. mutans). These bacteria are present in virtually all individuals. Various selective media like MSFA, MS, TYSCB, and BHI etc. supports the growth of S. mutans. On Mitis Salivarious sucrose bacitracin agar $S$. mutans has a characteristic colonial morphology, which permits its differentiation from other oral Streptococci. However in many instances, identification by the morphological criteria requires considerable experience.

Cell associated glucosyltransferase of Streptococcus mutans plays an important role in the development of dental caries in humans. Sucrose is a natural source of energy for this enzyme, and GTF is the key enzyme that catalyzes the conversion of sucrose to long-chain polysaccharides [2]. This insoluble glucan serves as a bridge for the bacterium to bind tightly to the tooth surface. After binding of $S$. mutans, it releases large amount of acids by fermenting a variety of sugars from the diet, which decalcify enamel, thus causing tooth decay or dental caries [3]. The reason behind the interest of studying GTF enzymes of $S$. mutans (serotypes C), is due to their ability to elicit protective immunity against experimental dental caries caused by implanted mutans streptococcal species [4].

The costs for operative dental treatment are significant both for individuals and society. Therefore, a need exists to target preventive measures and active treatment for the dental caries. A toothbrush can be used to remove plaque on accessible surfaces, but not between teeth or inside pits and fissures on chewing surfaces. When used correctly, dental floss removes plaque from areas which could otherwise develop proximal caries. Mouthwashes claim to prevent or reduce plaque

*Corresponding author: Sentila R, Department of Microbiology, PSG College of Arts and Science, Coimbatore, India, E-mail: sentilarajan@yahoo.in

Received April 09, 2013; Accepted June 12, 2013; Published June 28, 2013

Citation: Sentila R, Karthika S, Michael A, Gandhimathi A (2013) Protection against Dental Carries by Passive Immunization with Hen Egg Yolk Antibody Using Cell Associated Glucosyltransferase of Streptococcus mutans. J Med Microb Diagn 2: 125. doi:10.4172/2161-0703.1000125

Copyright: ( 2013 Sentila R, et al. This is an open-access article distributed under the terms of the Creative Commons Attribution License, which permits unrestricted use, distribution, and reproduction in any medium, provided the original author and source are credited. 
and chlorhexidine was probably the most effective and commonly used antibiotic [5]. Although most of the pathogenic and benign microorganisms are killed some of the strains of the Streptococcus have been found to be resistant to this chemical due to the formation of biofilm on the tooth surface in vivo. Dental caries causes many people to experience a great deal of continuous discomfort through impaired function and aesthetics as well as inconvenient treatment.

There are many reports suggesting the possibility of preventing dental caries by vaccination (active immunization) using antigens of mutans streptococci whole cell or one of its cariogenic factors CA-GTF. Chicken egg yolk has been recognized as an inexpensive alternative antibody source, Passive immunization with egg yolk immunoglobulin (IgY) against cell wall associated glucosyltransferase can prevent the tooth decay by immobilizing bacteria [6].

Hence, the present investigation is focused to generate chicken egg yolk antibodies against cell associated glucosyltransferase which effectively blocks the CA-GTase from binding to the tooth surfaces, thus inhibiting its growth and preventing the development of dental caries. Similar work was carried out previously with reliable records. Anti-CA-GTase antibody also inhibits the synthesis of insoluble glucan by the enzyme, thus assisting the elimination of the bacterium from the oral cavity [7].

\section{Materials and Methods}

\section{Experimental animal}

21 week old White leghorn chickens were purchased from LK poultry farm, Iyyampalayam (Near Paladam), Coimbatore. Chickens were maintained in the Layer Shed and were given ad libitum access to water and food.

\section{Confirmation of the standard strain}

Streptococcus mutans serotype c (MTCC No: 497) standard strain obtained from Depository at MTCC, Chandigarh, India, in a lyophilized form and after recovery confirmed by grams reaction, cultural characteristics, biochemical tests, biofilm formation and glass adherence test.

\section{Preparation of cell-associated glucosyltransferase antigen}

Streptococcus mutans serotype c standard MTCC (497) strain was cultivated on Brain Heart Infusion Broth supplemented with sucrose and incubated at $37^{\circ} \mathrm{C}$ for 24 hours aerobically. Further, the culture was preserved in $15 \%$ glycerol at $-20^{\circ} \mathrm{C}$ for further procedures.

The Streptococcus mutans c strain was cultivated onto a brain heart infusion broth with $5 \%$ sucrose and it was incubated for 18 hours at $37^{\circ} \mathrm{C}$. The culture was centrifuged at $10000 \mathrm{rpm}$ for 15 minutes and the pellet was washed three times with saline. Appropriate quantities of $8 \mathrm{M}$ urea solution was mixed with suspended washed pellet and the mixture was allowed to stand for one hour at room temperature in a metabolic shaker. This was subjected to centrifugation and the partially purified supernatant was again purified by Dialysis method. The purified form of mixture was centrifuged at $10000 \mathrm{rpm}$ for 15 minutes and the supernatant was precipitated $60 \%$ saturated ammonium sulfate and the precipitate was dissolved in $5 \mathrm{ml}$ of $50 \mathrm{M}$ phosphate buffer ( $\mathrm{pH} 7.5$ ). This solution was then subjected to dialysis. The fully purified mixture was again centrifuged $10000 \mathrm{rpm}$ for 15 minutes and the precipitate was removed. The resultant supernatant was used as an antigen [8].

\section{Immunization of Hens}

The White Leghorn hens were immunized intramuscularly at two different sites with the antigen solution. The first immunization was made by intramuscular injection with $1 \mathrm{ml}$ of antigen suspension prepared by emulsifying $0.5 \mathrm{ml}$ streptococcus mutans glucosyl transferase with an equal volume of Freund's Complete Adjuvant (FCA) as described by Sunwoo et al. [9]. The second dose of antigen was given after three weeks of the first inoculation with the same route and volume as the first immunization but the FCA was replaced by Freund's Incomplete Adjuvant (FIA). Booster inoculations were given at four-week intervals without adjuvant. Antibody titre in the serum was monitored to confirm the raise in the level of antibody after the booster doses.

\section{Collection and storage of eggs}

The eggs were collected daily and labelled with an identification number, and date. The collected eggs were refrigerated at $4^{\circ} \mathrm{C}$ until the isolation of the immunoglobulins. Yolk antibodies are stable in situ in the refrigerator for at least 6 months.

\section{Purification of IgY antibodies from egg yolk}

The egg yolk was separated from white and was washed with water to remove albumins. Approximately $10-15 \mathrm{ml}$ of yolk is obtained from an average sized egg. An equal amount of buffer S (10 Mm phosphate buffer, $100 \mathrm{mM} \mathrm{NaCI}$, pH 7.5 containing $0.01 \%$ sodium azide) was added to the yolk and stirred. To this mixture 10.5\% PEG 8000 in buffer $\mathrm{S}$ was added to a final concentration of $3.5 \%$. The mixture was stirred for 30 minutes at room temperature so that lipids got separated. The stirred mixture was centrifuged at $11000 \mathrm{rpm}$ for 20 minutes. The supernatant was filtered through double layered cheese cloth so that proteins and impurities were separated other than antibodies. The $42 \%$ PEG in buffer $\mathrm{S}$ was added to make a final concentration of $12 \%$ PEG. The mixture was stirred thoroughly and centrifuged at $11000 \mathrm{rpm}$ for 20 minutes. The pellet was redissolved in buffer $\mathrm{S}$ to the original yolk volume and the equal volume of $4 \mathrm{M}$ ammonium sulfate $(\mathrm{pH} 7)$ was added and incubated at $0^{\circ} \mathrm{C}$ for 30 minutes so that antibodies got saturated. The precipitate was centrifuged at $11000 \mathrm{rpm}$ for 20 minutes and the pellet was redissolved in buffer $\mathrm{S}$ without sodium chloride for overnight. This suspension was then subjected to dialysis using the same buffer. $\lg Y$ fraction obtained by dialysis was subjected [10] to further purification using DEAE cellulose ion exchange column chromatography.

\section{Determination of protein content in IgY fraction}

The total protein content was estimated by the method described by Lowry et al. [11]. The optical density (OD) was measured at $660 \mathrm{~nm}$. The OD value of IgY was compared with standard graph.

\section{SDS-PAGE}

The pooled IgY fractions (antibody samples) from other proteins were separated by Sodium Dodecyl Sulphate Polyacrylamide Gel Electrophoresis (SDS-PAGE) [12] with a $4 \%$ stacking and $10 \%$ separating gel. The samples were loaded into sample wells along with a known molecular weight markers (Low and Mid range markers, Genei Pvt. Ltd, Bangalore) and the electrophoresis was performed at $100 \mathrm{~V}$ current in a Tris glycine buffer system. When Bromo phenol blue dye reached at the bottom of the gel, the electrophoresis was stopped. The gel was removed and was stained with coomassie brilliant blue R-250 for 30 minutes. The gel was rinsed with distilled water and destained. The molecular weight of the proteins resolved estimated in comparison to the molecular weight markers. 


\section{Titration of antibodies-ELISA}

The immunological specificity of $\operatorname{IgY}$ elaborated against Streptococcus mutans antigen was examined by enzyme-linked immunosorbent assay (ELISA) [13]. In brief, wells of Microtiter plates were coated with antigen solution appropriately diluted with $0.05 \mathrm{M}$ carbonate buffer ( $\mathrm{pH}$ 9.6). After overnight incubation at $4^{\circ} \mathrm{C}$, the plates were washed, and PBS ( $\mathrm{pH} 7.4$ ) containing bovine serum albumin ( $1 \%$ in PBS) was added to the wells in order to block the uncoated surface. After being blocked each well was washed thrice with PBS, and IgY from immunized hens at different time intervals was applied to the well in duplicate for reaction with the antigen for 2 hours at $37^{\circ} \mathrm{C}$. After each well was washed again with PBSTween, HRP-conjugated rabbit antichicken IgG (Sigma Chemical Co.) diluted (1:1000) with PBSTween was added to each well, and the plate was incubated at $37^{\circ} \mathrm{C}$ for 2 hours. Each well was washed again and the reaction was stopped after $20 \mathrm{~min}$ with $4 \mathrm{~N} \mathrm{H}_{2} \mathrm{SO}_{4}$. The intensity of color developed was measured at 490 $\mathrm{nm}$ with a microplate reader.

\section{In vitro Assays}

\section{Assay of GTF activity}

About $3 \mathrm{ml}$ of sodium acetate buffer (100 mM; pH 6.2), 5\% sucrose was added with $1.5 \mathrm{ml}$ of crude bacterial enzyme, again $0.5 \mathrm{ml}$ of potassium phosphate buffer was reacted with above mixture. The crude mixture was incubated at $37^{\circ} \mathrm{C}$ for 2 hours. The water insoluble glucan was separated by centrifugation at $10,000 \mathrm{~g}$ for 5 minutes [14] and it was quantified by phenol sulphuric acid method.

\section{CA-GTF inhibition assay}

To evaluate total glucan synthesis inhibition by antibody a reaction mixture containing $10 \mathrm{~g} / \mathrm{L}$ sucrose and GTF $(2.5 \mu \mathrm{g}$ of protein $)$ and various concentrations of antibody in a total volume of $50 \mu \mathrm{L}$ of $\mathrm{KPB}\left(\mathrm{pH}\right.$ 6.0) was incubated at $37^{\circ} \mathrm{C}$ for $3 \mathrm{~h}$. After incubation, $75 \mu \mathrm{L}$ of $100 \%$ ethanol was added to the mixture, and synthesized glucan was precipitated at $-30^{\circ} \mathrm{C}$ for $30 \mathrm{~min}$. The precipitated glucan was centrifuged at $16,000 \mathrm{x}$ g for $15 \mathrm{~min}$ and washed three times with $60 \%$ ethanol. The precipitates were suspended in $50 \mu \mathrm{L}$ of $\mathrm{KPB}$ (pH 6.0), and the total amount of glucan was determined by the phenol-sulfuric acid method with glucose as a standard [15].

\section{Results}

21 week old white leghorn Hens were immunized intramuscularly with prepared bacterial antigens to generate anti-GTF antibodies. Booster doses were given in four weeks intervals and chickens were maintained with regular feed and water. The pre-immune sera and hyper immune sera were collected at specified time intervals during and after the various immunization schedules. After immunization the eggs were collected and stored at $4^{\circ} \mathrm{C}$ with proper marking of appropriate antigen name and date. Then the stored eggs were used for the purification of antibodies from yolks. The method used for purification of chicken egg yolk antibodies was PEG and ammonium sulphate precipitation described by [16] method. The suspension was subjected to Ammonium sulphate precipitation. The precipitate was desalted by dialysis to remove ammonium sulphate. After dialysis the IgY solution was lyophilized. The freeze dried IgY powder was used for further studies. The purity of chicken egg yolk antibodies and their molecular weight were determined by Sodium Dodecyl Sulphate Poly Acrylamide Gel Electrophoresis (SDS-PAGE), using 10\% gel according to the method of Laemmli [12]. The high molecular weight $180 \mathrm{kDa}$ protein band showed the purity of IgY. The standard protein marker was also run parallel along with the antibody sample (Figure 1). Protein content of freeze dried IgY antibodies were estimated by the method described by [11] using folin-ciocalteau reagent. The optical density of the BSA standard was used to plot the graph and the total protein concentration of the IgY. About $1 \mathrm{ml}$ of semi purified IgY antibody sample contains $3.9 \mathrm{mg} / \mathrm{ml}$ of egg yolk (Table 1). The IgY concentration in terms of total protein content was determined and monitored from the eggs collected before and after each immunization. The IgY content increased at each booster dose and remained stable after the fourth booster till the $150^{\text {th }}$ day which showed the maximum protein content. One of the objectives of this study is to find the specificity and dynamics of antibody rose against cell-associated glucosyltrasferase after periodic boosting the immune system of chickens. Partially purified samples are taken for analyzing antibodies, through ELISA method with duplicates. The titration of specific antibody raised was measured through optical density at $492 \mathrm{~nm}$ (Figure 2). Periodic boosting immune system of chickens raises antibody concentration (anti-GTF IgY) in egg yolk, constantly. The specificity of the antibody was also monitored using ELISA. In DEAE Cellulose ion exchange Column Chromatography the sample was eluted and fractions collected. The protein assay was done to all the samples to find the specific IgY concentration. The elute was collected in aliquots of $5 \mathrm{ml}$ and the IgY was found in the $2^{\text {nd }}$ to $4^{\text {th }}$ fraction. The specific IgY was observed in the fractions and it was determined by Sodium Dodecyl Sulphate Poly Acrylamide Gel Electrophoresis. GTF activities of cell-associated glucosyltransferase antigen were quantified by phenol-sulfuric acid method described by Dubois et al. [16]. The optical density of the glucose standard was used to plot the graph and GTF activity found to be $1.1 \mathrm{unit} / \mathrm{ml}$ (Figure 3). Total glucan synthesis by cell-associated GTF preparation from streptococcus mutans was significantly inhibited by the addition of antibodies against dental caries (Figure 4).

\section{Discussion}

Dental caries is a worldwide problem associated with plaque, microorganisms and the intake of refined carbohydrates. The mutans Streptococci specifically $S$. mutans is strongly associated with dental caries. They produce acids by fermentation of dietary sugars, which in sufficient quantities demineralizes the dental enamel. An attempt had been also made to provide preliminary data on the use of chicken egg yolk immunoglobulin raised against cell associated Streptococcus mutans antigen. Chickens were immunized with CA-GTF antigen of Streptococcus mutans to raise antibodies.

Chicken eggs present an ideal alternative antibody source to mammals, as the IgY in the chickens' blood is transported to the egg and accumulates in the egg yolk in large quantities. Hens usually lay about 280 eggs in a year. Egg yolk contains a considerable amount

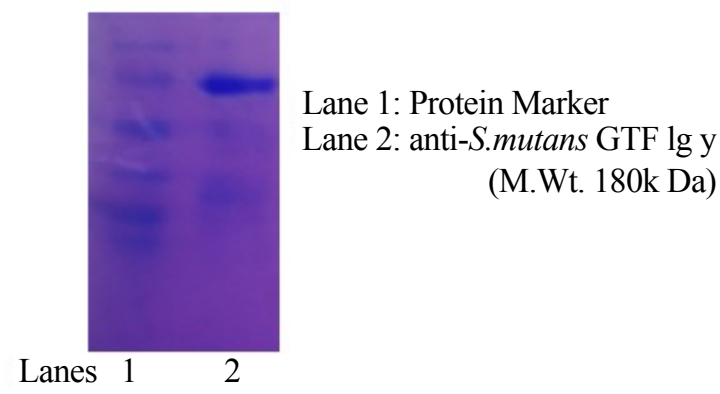

Figure 1: Characterization of IgY using SDS-PAGE. 
Citation: Sentila R, Karthika S, Michael A, Gandhimathi A (2013) Protection against Dental Carries by Passive Immunization with Hen Egg Yolk Antibody Using Cell Associated Glucosyltransferase of Streptococcus mutans. J Med Microb Diagn 2: 125. doi:10.4172/2161-0703.1000125

Page 4 of 5

\begin{tabular}{|c|c|}
\hline Egg collection (Days) & Total Protein Concentration $\mathbf{( m g / m l )}$ \\
\hline Pre-immune egg yolk & 0.3 \\
\hline Day 15 & 0.9 \\
\hline Day 30 & 1.1 \\
\hline Day 45 & 1.5 \\
\hline Day 60 & 2.3 \\
\hline Day 75 & 2.8 \\
\hline Day 90 & 3.2 \\
\hline Day105 & 3.6 \\
\hline Day 120 & 3.9 \\
\hline
\end{tabular}

Table 1: Estimation of Protein concentration in antibody fractions of chicken egg yolk.

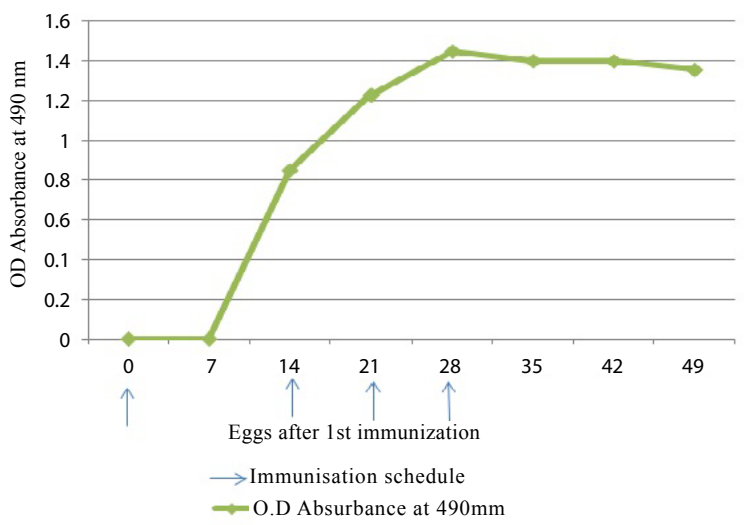

Figure 2: Titration of IgY using ELISA.

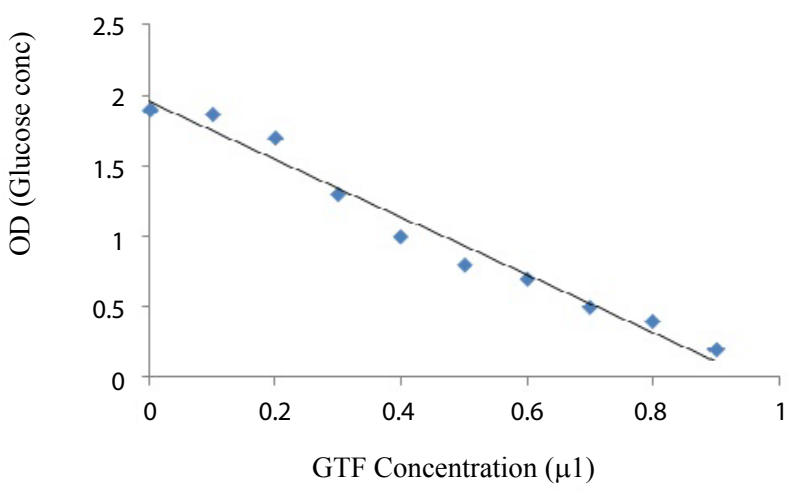

Figure 3: S. mutans GTF in association with activity.

of IgY, around 100-150 mg/egg [17]. Therefore, an immunized hen yields more than $40 \mathrm{~g}$ of IgY a year through eggs, equivalent to that from 40 rabbits. In the sense of animal welfare, the use of laying hens for antibody production represents a refinement and a reduction in animal use. It is a refinement in that the painful and invasive blood sampling or scarifying are replaced by collecting eggs. IgY technology, including the production and use of polyclonal $\operatorname{IgY}$ antibody $(\mathrm{Ab})$, is a highly innovative and an expanding branch in human and veterinary medicine.

Laboratory production of antibodies involves immunization and bleeding of animals, subjecting these animals to great stress. However, the use of chicken for this purpose is of dual advantage. The primary

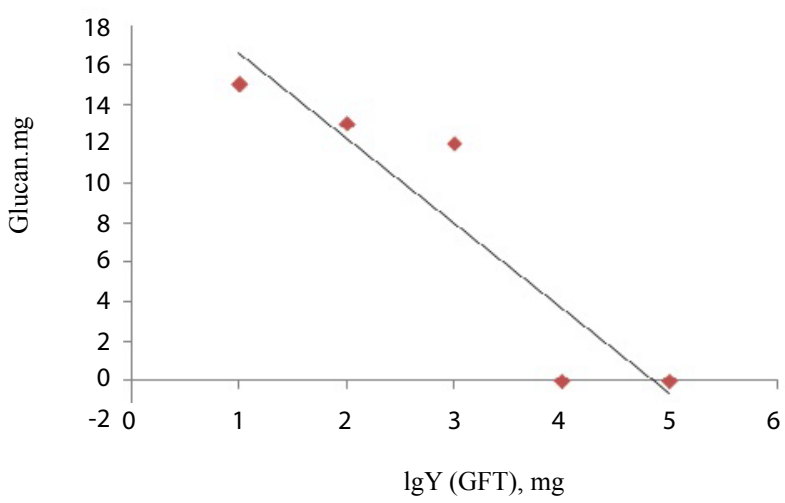

Figure 4: Inhibition of GTF activity.

advantage is production of high levels of antibodies by chickens than mammals, thus minimizing the number of animals needed. The second advantage is the recognition that the egg yolk obtained from immunized chicken as an excellent source of polyclonal antibodies for over a decade. The amount of antibodies generated by this avian is equal to or slightly greater than any other mammal used for obtaining antibodies.

Antibodies were generated against the CA-GTF antigen of Streptococcus mutans in chicken as an alternative source to mammalian antibodies. The process involves the preparation of crude Streptococcus mutans antigen, Immunization in chicken, characterization of antibodies and finding out the antibody titre in serum and egg yolk which was found to be 1:1280. Increase in the specific antibody concentration of egg yolks from immunized hens over the course of immunization period was monitored The antibodies against CA-GTF streptococcus mutans first appeared in serum on $7^{\text {th }}$ day after starting the immunization schedule. Then the antibodies were detected in egg yolk after a week. Protein content of freeze dried IgY antibodies were estimated by the method using folin-ciocalteau reagent [11]. About $1 \mathrm{ml}$ of semi purified IgY antibody sample contains $3.9 \mathrm{mg}$ of protein. The egg yolk antibodies were further purified by DEAE cellulose ion exchange column chromatography. The molecular weight of the purified IgY was confirmed as $180 \mathrm{KDa}$ through SDS PAGE [12]. The specificity of IgY antibodies was determined by ELISA. These antibodies can be used for developing a mouth rinse containing the specific monotype antibodies along with stabilizing agents which when orally administered reduces the number of streptococcus mutans in dental plaque and saliva by forming antigen- antibody complexes thereby neutralizing the plaque. The treatment of dental caries is otherwise done by chemicals and antibiotics having harmful side effects or else by painful removal of the teeth. The above approaches suggest that oral immunization could be an efficient method of preventing human dental caries.

\section{References}

1. Marsh PD (2003) Are dental diseases examples of ecological catastrophes? Microbiology 149: 279-294

2. Devulapalle KS, Mooser G (1994) Subsite specificity of the active site of glucosyltransferases from Streptococcus sobrinus. J Biol Chem 269: 1196711971.

3. Ackermans F, Klein JP, Ogier J, Bazin H, Cormont F, et al. (1985) Purification and characterization of a saliva-interacting cell-wall protein from Streptococcus mutans serotype f by using monoclonal-antibody immunoaffinity chromatography. Biochem J 228: 211-217.

4. Czerkinsky C, Russell MW, Lycke N, Lindblad M, Holmgren J (1989) Ora administration of a streptococcal antigen coupled to cholera toxin B subunit 
Citation: Sentila R, Karthika S, Michael A, Gandhimathi A (2013) Protection against Dental Carries by Passive Immunization with Hen Egg Yolk Antibody Using Cell Associated Glucosyltransferase of Streptococcus mutans. J Med Microb Diagn 2: 125. doi:10.4172/2161-0703.1000125

evokes strong antibody responses in salivary glands and extramucosal tissues. Infect Immun 57: 1072-1077.

5. Demuth DR, Irvine DC (2002) Structural and functional variation within the alanine-rich repetitive domain of streptococcal antigen I/II. Infect Immun 70: 6389-6398.

6. Smith DJ, King WF, Godiska R (2001) Passive transfer of immunoglobulin $Y$ antibody to Streptococcus mutans glucan binding protein B can confer protection against experimental dental caries. Infect Immun 69: 3135-3142.

7. Otake S, Nishihara Y, Makimura M, Hatta H, Kim M, et al. (1991) Protection of rats against dental caries by passive immunization with hen-egg-yolk antibody (lgY). J Dent Res 70: 162-166.

8. Horikoshi, Yoshikatsu, Ghen, Fujita, Isamu (1995) Cell-associated glucosyltransferase, an antibody thereto, and a dental caries prophylactic composition containing said antibody as an effective component 10: 227-235

9. Sunwoo HH, Nakano T, Dixon WT, Sim JS (1996) Immune responses in chickens against lipopolysaccharide of Escherichia coli and Salmonella typhimurium. Poult Sci 75: 342-345.

10. Polson A, Coetzer T, Kruger J, von Maltzahn E, van der Merwe KJ (1985) Improvements in the isolation of $\mathrm{Ig} Y$ from the yolks of eggs laid by immunized hens. Immunol Invest 14: 323-327.
11. Lowry OH, Rosebrough NJ, Farr AL, Randall RJ (1951) Protein measurement with the Folin phenol reagent. J Biol Chem 193: 265-275

12. Laemmli UK (1970) Cleavage of structural proteins during the assembly of the head of bacteriophage T4. Nature 227: 680-685.

13. Hatta H, Tsuda K, Ozeki M, Kim M, Yamamoto T, et al. (1997) Passive immunization against dental plaque formation in humans: effect of a mouth rinse containing egg yolk antibodies (IgY) specific to Streptococcus mutans. Caries Res 31: 268-274.

14. Al-Hebshi NN, Nielsen O, Skaug N (2005) In vitro effects of crude khat extracts on the growth, colonization, and glucosyltransferases of Streptococcus mutans. Acta Odontol Scand 63: 136-142.

15. Takahiko Oho, Yoshihiro Shimazaki, Morihide Mitoma, Mamiko Yoshimura (1999) Bovine Milk Antibodies against Cell Surface Protein Antigen PAcGlucosyltransferase Fusion Protein Suppress Cell Adhesion and Alter Glucan Synthesis of Streptococcus mutans.. J.Nutr.129:1836-1841.

16. Dubois M, Gilles KA, Hamilton JK, Rebers PA, Smith F (1956) Colorimetric method for determination of sugars and related substances. Anal Chem 28 350-356.

17. Rose ME, Orlans E, Buttress N (1974) Immunoglobulin classes in the hen's egg: their segregation in yolk and white. Eur J Immunol 4: 521-523.

This article was originally published in a special issue, Allergy \& Immunology handled by Editor. Dr. Edwin Dias, Rajiv Gandhi University, India 